
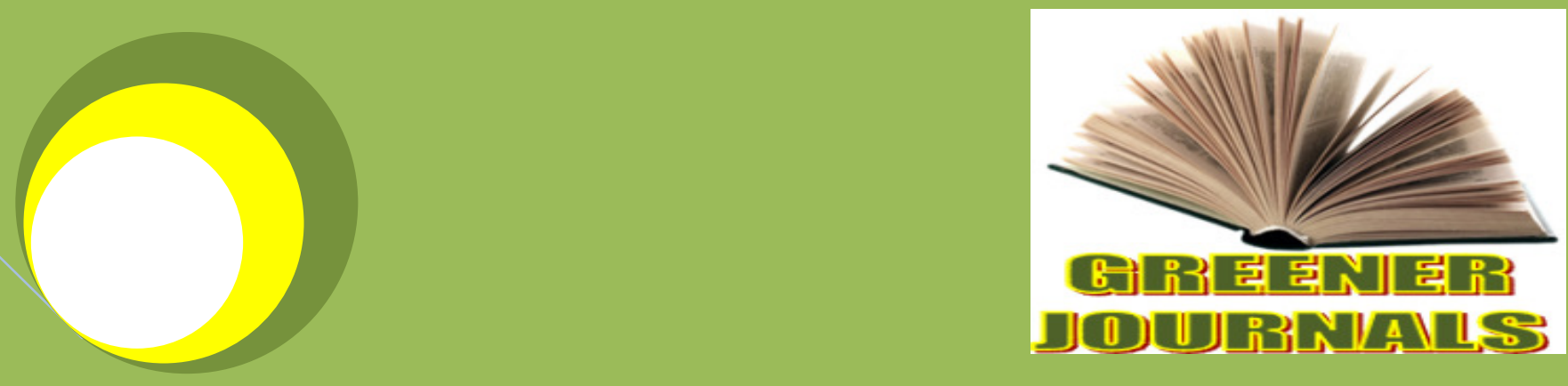

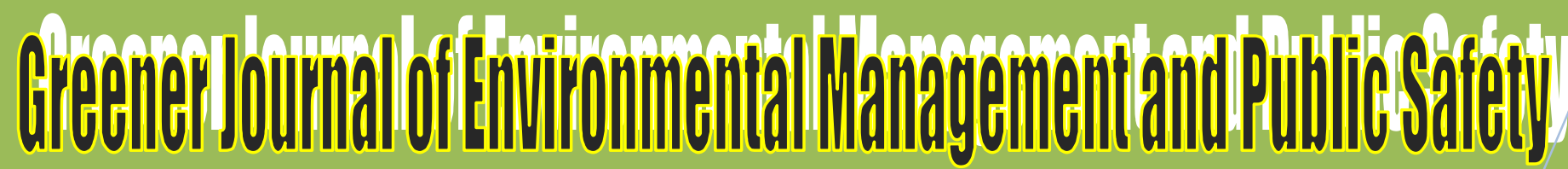
ISSN: 2354-2276

Selected Trace Metals Analysis of Total Suspended particulate Matter in Rural Areas in Edo state, Nigeria By

Ediagbonya T. F.

Ukpebor E. E.

Okieimen F. E. Akpojivi V. O. 


\title{
Selected Trace Metals Analysis of Total Suspended particulate Matter in Rural Areas in Edo state, Nigeria
}

\author{
*Ediagbonya T. F., Ukpebor E. E., Okieimen F. E. and Akpojivi V. O.
}

Department of Industrial Chemistry, Western Delta University,Oghara, Delta state.

*Corresponding Author's Email: thompsonisnow@yahoo.com, phone: +23480696066577 +2347059438029 +2348125819251.

\begin{abstract}
Particulate matter was captured from five different sites using SKC Air Check gravimetric sampler Model 21-5000 serial no 20537 and a glass fibre filter between the months of December 2008 and April 2009. The glass fibre filters were analysed for nine trace metals - Fe, $\mathrm{Cu}, \mathrm{Zn}, \mathrm{Cd}, \mathrm{Mn}, \mathrm{Pd}, \mathrm{Ni}, \mathrm{Cr}$ and $\mathrm{Co}$ (by Atomic Absorption spectrophotometric (AAS). The data obtained were subjected to factor analysis. Enrichment factors of various elements relative to crustal abundance for the air filters indicate that input of the majority of elements is due to crustal resuspended soil induced by wind and traffic. The element $\mathrm{Cd}$ was moderately enriched. The mean ambient temperature was in the range of $26.40^{\circ} \mathrm{C}$, the relative humidity was in the range of $70.00-72.60 \%$ and the mean wind speed was in the range of $0.13-0.34 \mathrm{~m} / \mathrm{s}$.
\end{abstract}

Key words: Trace metals, Enrichment Factor, Atomic Absorption Spectroscopy, Total Suspended Particulate Matter, Rural area.

\section{INTRODUCTION}

Rural dwellers are oblivious of the deleterious effect of particulate matter. The major way of waste disposal in the rural area is by burning. Although, there is no single method of waste treatment or disposal that completely eliminate all risks to public and environment. Incineration has been found to be the most effective overall for destroying infectious and toxic components and for attenuating waste volume and weight (Dempsey and Oppelt, 1993; Lee and Huffman, 1996). Other human activities (anthropogenic sources) include wood stoves, road construction and different artisans.

Pollution resulting from suspended particulate matter and carbon monoxide may place an undue burden on the respiratory system and contribute to increased morbidity and mortality, especially among susceptible individuals in the general population (WHO Report, 1968). Particulate greater than $3 \mu \mathrm{m}$ in diameter are likely to be collected in the lung Lobar bronchi. Smaller particulates (less than $3 \mu \mathrm{m}$ ) end up in the alveoli, the thoracic or lower regions of the respiratory tract, where more harm can be done Jacko and Timothy (2003). Air pollution, both natural and manmade affect climate Chatwal (1997).

Atmospheric particles have numerous effects. The most conspicuous of these is attenuation and distortion of visibility, they provide active surfaces upon which heterogeneous atmospheric chemical reactions can occur and nucleation bodies for the condensation of atmospheric water vapour, thereby exerting a significant influence upon weather and air pollution phenomena.

Particulate matter has a net detrimental effect upon the environment or upon something of value in the environment Manghan (1991). The severity of contamination by pollution increases with emission source strength and the atmospheric mixing of the pollutants Obioh et al. (1993).

In terms of adverse effects on human health, particulate matter is perhaps the most important air pollutant. Though, much has been reported about particulate matter and its associated health problems, there is no established standard or guidelines as to the levels of particulate matter in the ambient air required to cause hazard. Mortality based epidemiological studies have linked air pollution episodes to health problems Bobak and Leon, 1992; Dockery et al., 1993; Ostro, 1993; Lipfert and Wyzga,1995;Pope and Dockery, 1999; Wooldruff et al., 1997; Schwartz, 1994; XU et al., 1994; Pope and Kalstan, 1996; Anderson et al., 1992; Lin and Hwang, 1996).

Toxicological study has equally implicated particulate air pollution in adverse health effects Anderson et al.,1992; Lin and Hwang, 1996; Manderly, 1994). 
Objectives of this study are to analyse nine trace metals in the glass fibre filter using Atomic Absorption spectroscopy and also to identify these elements which are abnormally enriched in the atmosphere.

Some of these metals are well known to cause chronic and acute poisoning of important organs in the body, cancer, dermatitis and ulcers of the skin Benign preumoconiosis, manganese poisoning and cause damage of mucous membranes and silicosis. National Institute for Occupational Safety and Health (NIOSH), 2002; Park et al., 1999; International Agency for Research on Cancer, 1997; Mohebbi and Abd, 2007). These metals enter the atmosphere from both anthropogenic and biogenic sources.

\subsection{Materials and Methods}

\subsection{Sampling Site}

Sampling was done in Obaretin in Ikpoba-Okha L.G.A Edo State in Niger Delta region of Nigeria. The rural community is sparsely distributed with a population estimate of few thousand of inhabitant, the settlement is situated along the main road i.e Nodal Settlement. There are thick rubber plantations and industrial farms all located behind the community.

The rural dwellers engage themselves in farming, hunting, rubber tapping and rural or intra-transportation due to the accessibility of the community to the main road. Also, the people engage in cassava processing, smoking of fishes, and their major way of waste disposal is by burning. The main road that led to the community is untarred. Other human activities in this locality include paving of roads and different artisans. All these activities aforementioned are veritable generators of particulates to the environment.

The major human activities in this region that generate cumbersome pollution are the particulate generate from bike, vehicle exhaust, and bush burning and resuspended particle from the untarred road.

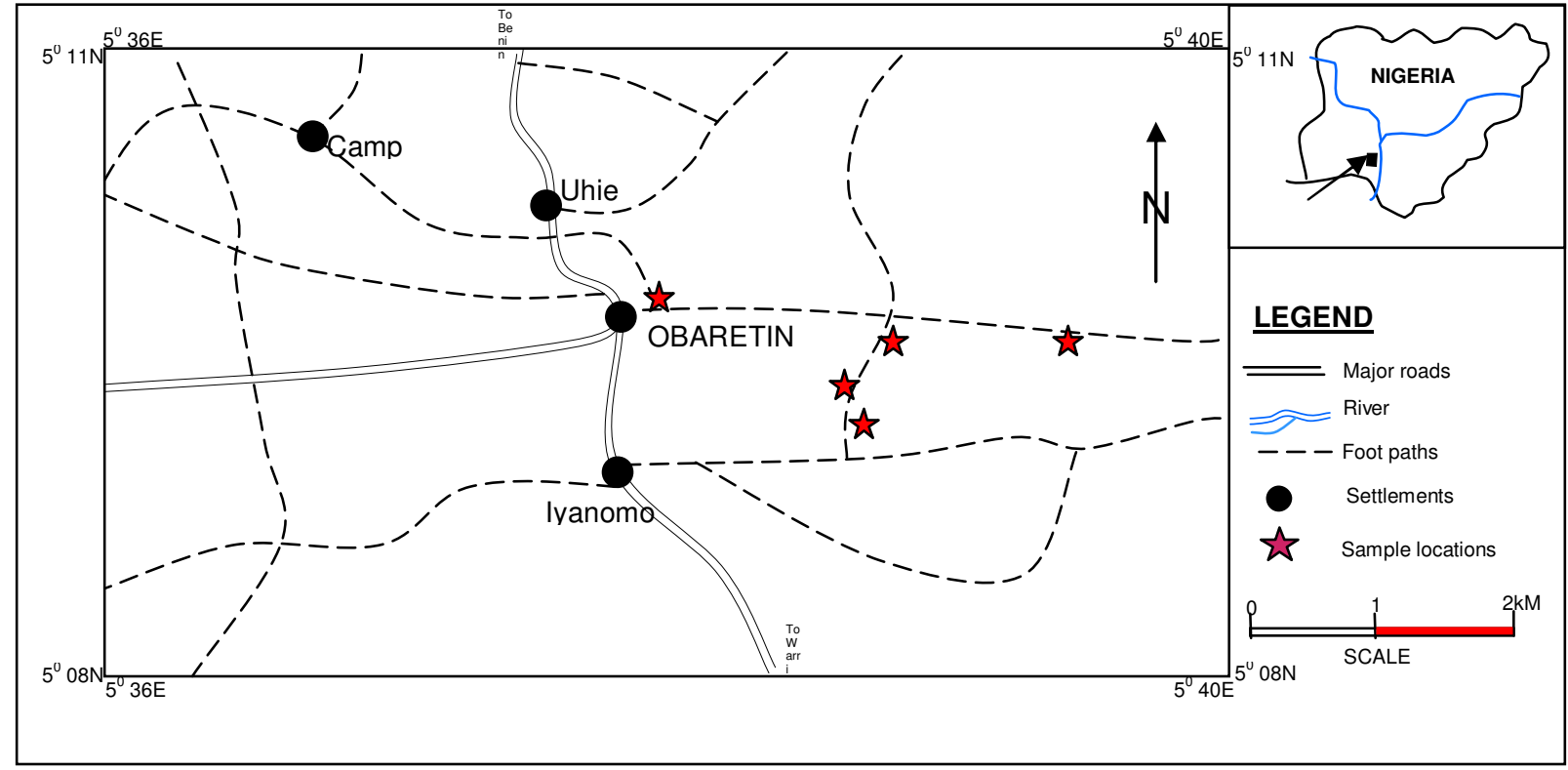

FIG. 1: MAP OF OBARETIN AND ENVIRONS SHOWING THE SAMPLED LOCATIONS 
Table 1 monitoring sites and their co-ordinates

\begin{tabular}{|c|c|c|c|}
\hline $\mathbf{S} / \mathbf{N}$ & Site Code & Co-Ordinates & Site Descriptions \\
\hline 1 & $\mathrm{RH}_{\mathrm{A}}$ & $\begin{array}{l}\mathrm{N}^{\circ} 06^{\circ} 0943.3 \\
\mathrm{E}^{\circ} 5^{\circ} 38^{\prime} 49.2^{\prime \prime}\end{array}$ & Mud house detached, kitchen unceiled roof \\
\hline 2 & $\mathrm{RH}_{\mathrm{B}}$ & $\begin{array}{l}\text { N06 }^{\circ} 0946.9 \\
\text { E005 }^{\circ} 38^{\prime} 44.7\end{array}$ & Mud house detached, kitchen unceiled roof \\
\hline 3 & $\mathrm{RH}_{\mathrm{C}}$ & $\begin{array}{l}\mathrm{N}^{\circ} 06^{\circ} 09^{\prime} 46.9^{\prime \prime} \\
\mathrm{E}^{\prime \prime} 05^{\circ} 38^{\prime} 48.1^{\prime \prime}\end{array}$ & Mud house detached, kitchen unceiled roof \\
\hline 4 & $\mathrm{RH}_{\mathrm{D}}$ & $\begin{array}{l}\mathrm{N}^{\circ} 6^{\circ} 09 \\
\mathrm{E}^{\circ} 5^{\circ} 38^{\circ} \\
\end{array}$ & Mud house detached, kitchen unceiled roof \\
\hline 5 & $\mathrm{RH}_{\mathrm{E}}$ & $\begin{array}{l}N_{06}^{\circ} 0935.8 \\
E 005^{\circ} 38^{\prime} 30.4^{\prime \prime}\end{array}$ & Mud house detached, kitchen unceiled roof \\
\hline
\end{tabular}

\subsection{Sample collection:}

SKC Air Check XR5000 high volume, Gravimetric sampler model 210-5000, High volume Gravimetric sampler model 210-5000 serial No. 20537 with a Whatman glass fibre filter were used to capture the particles. The particles were collected at a flow rate of $2 \mathrm{l} / \mathrm{min}$ for eight hours and the sampler was placed between the heights of $1.5-2 \mathrm{~m}$ of human. The Whatman glass fibres used were conditioned in a controlled room temperature for at least $24 \mathrm{hrs}$ before pre-and post weighing. The sampling was done from Dec. 2006-April 2009.

\subsection{Sample Digestion and Measurement:}

The trace metals $\mathrm{Pb}, \mathrm{Cd}, \mathrm{Ni}, \mathrm{Cu}, \mathrm{Co}, \mathrm{Fe}, \mathrm{Zn}, \mathrm{Cr}$ and $\mathrm{Mn}$ were determined by AAS (Thermo electron corporation Atomic Absorption spectrometry, S. Series)

A portion of the effective filter and the respirable foam were digested separately with $20 \mathrm{~mL} 1: 1 \mathrm{HNO}_{3}$ in a beaker and covered with a watch glass which was concentrated to about $50 \mathrm{ml}$ on a hot plate at $150-180^{\circ} \mathrm{C} 10 \mathrm{ml}$ of 1:1 $\mathrm{HNO}_{3}$ was added to repeat it. The extract was filtered through a 541 filter paper, the filter paper and the beaker was washed with $0.25 \mathrm{M} \mathrm{HNO}_{3}$. The filtrate was transferred and weighted into $50 \mathrm{ml}$ volumetric flask. The chemical and reagents used for analysis were analar grade.

\subsection{Data Analysis:}

The results got from this work were subjected to descriptive statistics and enrichment factor computation. In this work, Iron was chosen as the reference element during the computation of enrichment factor. (Jian et al., 2004; Ukuo et al., 2005), used Iron as a reference.

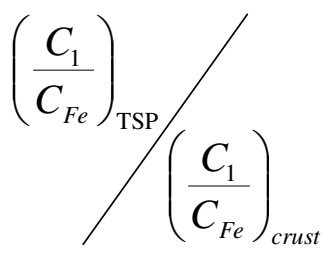

where $C_{1}$ is the concentration of the element considered in the TSP of the crust and $C_{F e}$ is the concentration of the reference element $(\mathrm{Fe})$.

The elemental concentration in the crust used in this study was got from Wedephol Wedephol (1968). An enrichment factor close to 1 indicates that the relative concentration of a given element is identical to that which is present in the soil. An enrichment factor greater than 1 indicates that the element is more abundant in the air relative to that found in the soil, while values less than 1 suggests a depletion of the element in the air over that found in soil. 


\section{RESULTS AND DISCUSSION}

\section{Spatial Distribution of Chemical Composition of Particulate During Dry Season in Obaretin.}

In addition to particulate matter mass limit values which are based on health impact, recent European Union(EU) Standard target(As, Cd, Ni, Pb) limit for metals $6 \mathrm{ng} / \mathrm{m}^{3}$ for As, $5 \mathrm{ng} / \mathrm{m}^{3}$ for $\mathrm{Cd}, 20 \mathrm{ng} / \mathrm{m}^{3}$ for Ni and $500 \mathrm{ng} / \mathrm{m}^{3}$ for $\mathrm{Pb}$.

Table 3.1.1, 3.1.2 and 3.1.3 show the mean concentration of the trace metal composition of the various locations in rural areas, the total mean concentration of the trace metal and the Enrichment factor.

The total mean concentration values of the analysed trace metals are: $\left(\mathrm{Fe}: 2.56 \mathrm{mg} / \mathrm{m}^{3}, \mathrm{Zn}: 0.034 \mathrm{mg} / \mathrm{m}^{3}, \mathrm{Cu}\right.$ : $0.122 \mathrm{mg} / \mathrm{m}^{3}, \mathrm{Mn}: 0.163 \mathrm{mg} / \mathrm{m}^{3}, \mathrm{Cd}: 0.404 \mathrm{mg} / \mathrm{m}^{3}, \mathrm{~Pb}: 1.19 \mathrm{mg} / \mathrm{m}^{3}, \mathrm{Cr}: 0.10 \mathrm{mg} / \mathrm{m}^{3}$ ) Ni and Co were below detection limit. The spatial distribution were insignificant $(\mathrm{P}>0.05)$.

From Table 3.1.3, Cd was highly enriched and $\mathrm{Pb}$ was moderately enriched. The mean ambient temperature was in the range of $28.65-31.65^{\circ} \mathrm{C}$, the relative humidity was in the range of $66.20-73.30 \%$ and mean wind speed was in the range of $0.28-0.93 \mathrm{~m} / \mathrm{s}$. Table 3.4 .3 shows the mean range of ambient temperature was $26.40-30.10^{\circ} \mathrm{C}$, the mean range of relative humidity was $67.20-70.20 \%$ while the mean range wind speed was $0.13-0.34 \mathrm{~m} / \mathrm{s}$.

\section{Source Identification of Total Suspended Particulate Matter.}

In essay to find a common metal source, factor analysis was carried out which includes correlation coefficient of metal concentration and principal component analysis with Varimax rotation and cluster analysis. Table 3.2.1 shows the correlation coefficient of the metal concentration.

\section{Table 3.2.1: Correlation Coefficients}

\begin{tabular}{|l|l|l|l|l|l|}
\hline & $\mathrm{Fe}$ & $\mathrm{Zn}$ & $\mathrm{Cu}$ & $\mathrm{Cd}$ & $\mathrm{Pb}$ \\
\hline $\mathrm{Fe}$ & 1 & -0.322 & -0.505 & -0.105 & 0.468 \\
\hline $\mathrm{Zn}$ & -0.322 & 1 & -0.148 & 0.282 & 0.642 \\
\hline $\mathrm{Cu}$ & -0.505 & -0.148 & 1 & 0.733 & -0.736 \\
\hline $\mathrm{Cd}$ & -0.105 & 0.282 & 0.733 & 1 & -0.099 \\
\hline $\mathrm{Pb}$ & 0.468 & 0.642 & -0.736 & -0.099 & 1 \\
\hline
\end{tabular}

From the PCA with varimax rotation, two components were extracted which explained $80.46 \%$ of the total variance.

Table 3.2.2: Principal Component Matrix

\begin{tabular}{|l|l|l|}
\hline & Component \\
\hline & 1 & 2 \\
\hline $\mathrm{Fe}$ & -0.695 & 0.027 \\
\hline $\mathrm{Zn}$ & 0.271 & 0.937 \\
\hline $\mathrm{Cu}$ & 0.907 & -0.376 \\
\hline $\mathrm{Cd}$ & 0.773 & 0.218 \\
\hline $\mathrm{Pb}$ & -0.486 & 0.861 \\
\hline
\end{tabular}

The rotated component matrix showed that from the two components extracted from PCA $\mathrm{Cu}$ and Cd loaded positively with the first component, while Fe loaded negatively with the first component suggesting incineration of waste as a major source of the trace metal. For the second component $\mathrm{Zn}$ and $\mathrm{Pb}$ loaded positively suggesting vehicular related emission as a major source of the trace metal. Figure 2 below shows the rotated component plot. 


\section{Component Plot in Rotated Space}

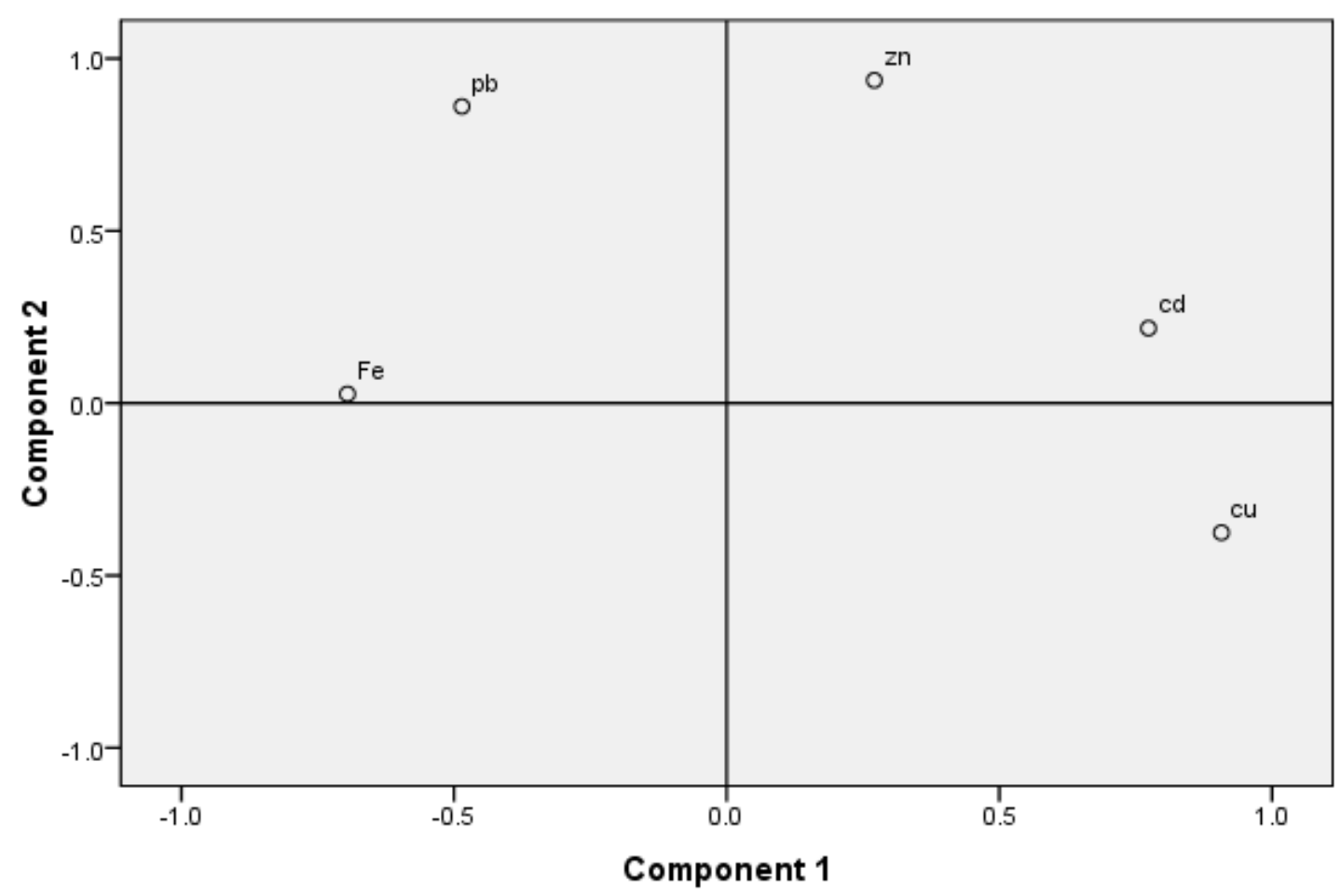

Figure 2: Rotated Component Plot

\section{Cluster Analysis}

Fig 3.3.1 Shows the Hierarchical Cluster Analysis. This cluster confirms two major clusters arrangement of the trace metal concentration and distribution at five monitoring sites. Cluster comprises Site 5 which is a unique cluster while the second cluster is made up of Site 1 and Site 3.

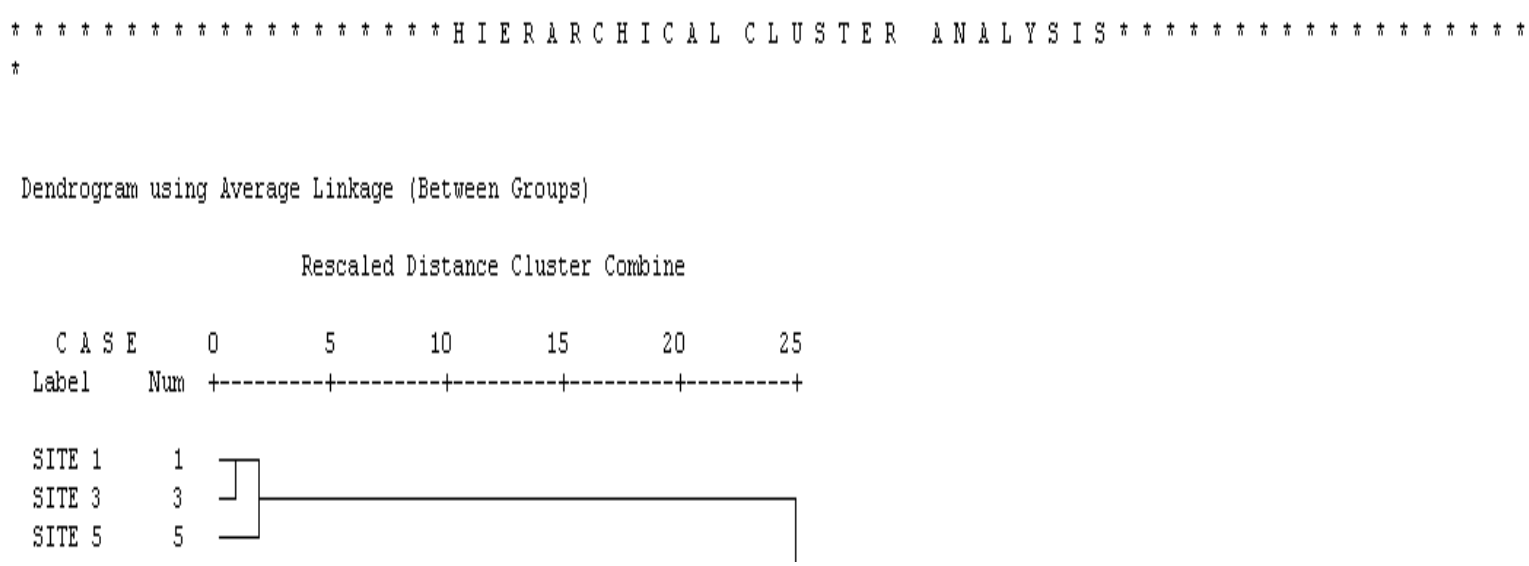

Fig 3.3.1: Dendrogram Showing Sites Cluster of TSP in Obaretin 
Table 3.3.1: The Mean Concentration of Trace Metal in Total Suspended Particulate Matter during Dry Season in Obaretin $\left(\mathrm{mg} / \mathrm{m}^{3}\right)$

\begin{tabular}{|l|l|l|l|l|l|}
\hline & \multicolumn{1}{|c|}{ Mean RHA } & \multicolumn{1}{|c|}{ MeanRHB } & \multicolumn{1}{|c|}{ Mean RHC } & \multicolumn{1}{|c|}{ Mean RHD } & \multicolumn{1}{c|}{ Mean RHE } \\
\hline $\begin{array}{l}1 . \\
\mathrm{Fe}\end{array}$ & $1.450 \pm 0.495$ & $3.500 \pm 2.869$ & $1.300 \pm 0.721$ & $4.450 \pm 0.3323$ & $2.100 \pm 0.000$ \\
\hline $\begin{array}{l}2 . \\
\mathrm{Zn}\end{array}$ & $0.080 \pm 0.070$ & $\mathrm{BDL}$ & $0.115 \pm 0.000$ & $0.065 \pm 0.014$ & $0.067 \pm 0.042$ \\
\hline $\begin{array}{l}3 . \\
\mathrm{Cu}\end{array}$ & $0.120 \pm 0.057$ & $0.163 \pm 0.106$ & $0.130 \pm 0.070$ & $0.105 \pm 0.078$ & $0.093 \pm 0.075$ \\
\hline $\begin{array}{l}4 . \\
\mathrm{Mn}\end{array}$ & $0.1633 \pm 0.0551$ & $\mathrm{BDL}$ & $\mathrm{BDL}$ & $\mathrm{BDL}$ & $\mathrm{BDL}$ \\
\hline $\begin{array}{l}5 . \\
\mathrm{Cd}\end{array}$ & $0.4815 \pm 0.2270$ & $0.4130 \pm 0.1952$ & $0.4125 \pm 0.2595$ & $0.4125 \pm 0.2595$ & $0.2985 \pm 0.01619$ \\
\hline $\begin{array}{l}6 . \\
\mathrm{Pb}\end{array}$ & $1.250 \pm 0.636$ & $1.100 \pm 0.520$ & $1.100 \pm 0.520$ & $1.250 \pm 0.636$ & $1.250 \pm 0.636$ \\
\hline $7 . \mathrm{Cr}$ & $0.200 \pm 0.000$ & $\mathrm{BDL}$ & $\mathrm{BDL}$ & $\mathrm{BDL}$ & $0.20 \pm 0.000$ \\
\hline $8 . \mathrm{Ni}$ & $\mathrm{BDL}$ & $\mathrm{BDL}$ & $\mathrm{BDL}$ & $\mathrm{BDL}$ & $\mathrm{BDL}$ \\
\hline $\begin{array}{l}9 . \\
\mathrm{Co}\end{array}$ & $\mathrm{BDL}$ & $\mathrm{BDL}$ & $\mathrm{BDL}$ & $\mathrm{BDL}$ & $\mathrm{BDL}$ \\
\hline
\end{tabular}

$\mathrm{BDL}=$ Below Detection Limit

Table 3.3.2: The Descriptive Statistics of Total Suspended Particulate Matter $\left(\mathrm{mg} / \mathrm{m}^{3}\right)$ and Enrichment Factor during Dry Season In Obaretin (Urban Area)

\begin{tabular}{|l|l|l|l|l|l|}
\hline & Min & Max & Mean & SD & Enrichment Factor \\
\hline $\mathrm{Fe}$ & 1.3000 & 4.4500 & 2.5600 & 1.3681 & 1.000 \\
\hline $\mathrm{Zn}$ & 0.0000 & 0.0800 & 0.0340 & 0.0353 & 0.158 \\
\hline $\mathrm{Cu}$ & 0.0900 & 0.1600 & 0.1222 & 0.0268 & 0.570 \\
\hline $\mathrm{Mn}$ & 0.1600 & 0.1600 & 0.1633 &. & 0.033 \\
\hline $\mathrm{Cd}$ & 0.3000 & 0.4800 & 0.4036 & 0.0659 & 550.190 \\
\hline $\mathrm{Pb}$ & 1.1000 & 1.2500 & 1.1900 & 0.0822 & 10.840 \\
\hline $\mathrm{Cr}$ & 0.0000 & 0.2000 & 0.1000 & 0.1414 & 0.413 \\
\hline
\end{tabular}

Table 3.3.3: Typical concentration of some traces metal in air concentration range $\left(\mu \mathrm{g} / \mathrm{m}^{3}\right)$

\begin{tabular}{|l|l|l|}
\hline Element & Urban & Background \\
\hline $\mathrm{Fe}$ & $01 .-10$ & $0.04-2$ \\
\hline $\mathrm{Pb}$ & $0.1-10$ & $0.02-2$ \\
\hline $\mathrm{Mn}$ & $0.01-0.5$ & $0.001-0.01$ \\
\hline $\mathrm{Cd}$ & $0.0005-0.5$ & $0.0001-0.1$ \\
\hline $\mathrm{Zn}$ & $0.02-2$ & $0.003-0.1$ \\
\hline $\mathrm{V}$ & $0.02-0.2$ & $0.001-0.05$ \\
\hline
\end{tabular}

Source: Mirosla R. and Vladimir N. B. Mirosla and Vladiir (1999) 
Table 3.3.4: The Range and Mean of the Ambient Temperature Relative Humidity and Wind Speed between December 2008 and April 2009 for the Various Sampling Locations in Obaretin

\begin{tabular}{|c|c|c|c|c|c|c|c|}
\hline & & \multicolumn{2}{|c|}{ Ambient temperature ( $\left.{ }^{\circ} \mathbf{C}\right)$} & \multicolumn{2}{c|}{ Relative humidity (\%) } & \multicolumn{2}{c|}{ Wind Speed $\left({ }^{\mathrm{m}} / \mathrm{s}\right)$} \\
\hline S/NO & Site Code & Range & Mean & Range & Mean & Range & Mean \\
\hline 1. & RHA & $27.10-35.20$ & 30.10 & $59.14-70.00$ & 68.40 & $0.0-0.3$ & 0.20 \\
\hline 2. & RHB & $28.10-33.10$ & 30.00 & $66.20-72.60$ & 69.20 & $0.0-0.4$ & 0.25 \\
\hline 3. & RHC & $25.10-29.70$ & 26.40 & $68.10-71.20$ & 70.20 & $0.0-0.5$ & 0.34 \\
\hline 4. & RHD & $25.00-28.00$ & 26.50 & $66.40-70.00$ & 69.80 & $0.0-0.6$ & 0.30 \\
\hline 5. & RHE & $28.10-34.50$ & 30.20 & $50.10-70.00$ & 67.20 & $0.0-0.2$ & 0.13 \\
\hline
\end{tabular}

\section{ACKNOWLEDGEMENT}

We gratefully acknowledge the support of Mr. Ufuoma Asagba, Mr. Magnus Legmah, Mrs. Justina Ukpebor, Mr. Eddy Olumese, Mr. Obozakhai, Mr. Ezeh Joseph Onuwa, Mr. Ogaga Tebehaevu and Mr. Okungbowa Godwin Nosa for their immeasurable assistance.

\section{REFERENCES}

Dempsey CR and Oppelt ET (1993). Incineration of harzardous waste: Critical Review Update Air Waste 43, 25-49.

Lee CCand Huffman GL (1996). Medical Waste Management/Incineration). Journal of Hazardous Materials 35, 34953501.

WHO Report (1968). Research into Environmental Pollution WHO Technical Report Series 406.

Jacko R and Timothy C (2003). Air Pollution and Noise Control, Purduc University, Lafayette, Indiana.

Chatwal GR(1997). Encyclopedia of Environmental Air Pollution, vol. III, New Delhi Animal Publication,

Manghan SE (1991). Environmental Chemistry, $5^{\text {th }}$ Edition, chapter Lewis Publisher Chelsea Milligan, U.S.A.

Obioh IG, Oluwole AF and Akeredolu FA (1993). "Lead Emissions and Source Strength in Nigeria: 1998 Inventory" In heavy Metals in the Environment. Allan and Nriagu (Eds). Proceeding of an International conference Toronto Canada, 12-17 Sept 1993 (EP publisher's' Edinburgh ISBN 0-905 941-51-9, 271-274.

Bobak Mand Leon DA (1992). Air Pollution and Infact Mortality in Czech Republic 1986-1988, Lanert 340,1010-1014.

Dockery BW, Pope CA III, XU X, Spengler JD, Ware JH, Fay ME, Ferris BG, Speizer FE (1993). An Association Between Air Pollution and Mortality in Six US Cities. New England Journal of Medicine 329, 1753-1759.

Ostro B (1993). The Association Between Air Pollution and Mortality: Examining the Case Inference. Archives of Environmental Health 48,336-342.

Lipfert FWand Wyzga RE (1995). Air Pollution and Mortality: Issues and Uncertainties. Journal of Air and Waste Management Association 45, 949-966.

Pope CA and Dockery DW (1999). Epidemiology of Particle Effects. In: Holdgate, S.T., Samet, J.M. Koren, H.S., Maynard, R.L. Eds. Air Pollution Health. Academic Press London. Pp 619-634.

Wooldruff TJ, Grillo J, Shoendoiff KC (1997). The Relationship between Selected Causes of Post-Neonatal Infant Mortality and Particulate Air Pollution in United State. Environmental Health Perspectives 105, 608-617.

Schwartz J (1994). PM $_{10}$, Ozone and hospital Admission for the Elderly in Minneapolis St. Paul Minnesota Achieves of Environmental Health 49, 366-373.

XU, X, Goa J, Dockery DW, Chen Y (1994). Air Pollution and Mortality in Residential Areas of Beijing, China: Archives of Environmental Health 49, 216-222.

Pope CA III and Kalstan LS (1996). synoptic Weather Modeling and Estimates of Exposure Response Relationship Between Daily Mortality and Particulate Air Pollution Environmental Health Perspective 104, 414-420.

Anderson KR, Avole L, Edward SA, Shamoo DA, Peng RC, Linn WS, hackney JD (1992). Controlled Exposure of Volunteers to Respirable Carbon and Sulphuric Acid Aerosol. Air and Waste Management Association 770-776.

Lin S and Hwang S (1996). Fertility Rates Among Lead Workers and Professional Bus Drivers: A Comparative Study. Annal of Epidemiology 6, 201.

Manderly JC (1994). Toxicological and Epidemiological Evidence for Health Risks from inhaled Engine Emission. In: Symposium of Risk Assessment of Urban Air: Stockholm, Sweden, Environmental Health Perspective 102 (Supp 14) $165-171$.

National Institute for Occupational Safety and Health (NIOSH) (2002). Hazard Review: Health effects of Occupational exposure to respirable crystalline silica. No. 2002-129, DHHS (NIOSH) Publication, Cincinnati. 
Park CG, Conrad K, Cooper GS (1999). Occupational exposure to crystalline silica and autoimmune disease. Envron. Health Perspect 107, 793-802.

International Agency for Research on Cancer (1997). IARC monographs on the evaluation of the carcinogenic risk of chemicals to humans: Silica and Some silicates, International Agency for Research on Cancer, Lyon.

Mohebbi I and Abd Rad I (2007). Secondary Spontaneous pneunomophorax in rapidly progressive forms of silicosis characterization of pulmonary function measurements and clinical patterns. Toxicol. Ind. Health 23, 125-32.

Jian Zheng ${ }^{\mathrm{ab}}$, Mingguang Tan ${ }^{\mathrm{a}}$, Yasuyuki Shibata ${ }^{\mathrm{a}}$, Atsushi Tanaka ${ }^{\mathrm{b}}$, Yun Li ${ }^{\mathrm{a}}$, Guilin Zhang ${ }^{\mathrm{a}}$, Yuanmao Zhang ${ }^{\mathrm{c}}$, Zuci $\operatorname{Shan}^{\mathrm{c}}$ (2004). Characteristic of Lead isotope ratios and elemental concentration in $\mathrm{PM}_{10}$ fraction of air borne particulate matter in Shanghai after the phase out of leaded gasoline, Atmospheric environment 38, 1191-1200.

Okuo James M and Ndiokwere CL (2005). Elemental concentration of total suspended particulate matter on relation to air pollution in Niger Delta: A Case Study of Warri: Trends in Applied Science Research 1(1): 91-96.

Wedephol KH (1968). Origin and Distribution of the Elements, L. H. Ahren Ed., Pergimon Press, London, England. p99.

Mirosla R and Vladiir N B (1999). Practical Environmental Analysis pg 128-129. Royal Society of Chemistry. 